\title{
HUMIDITY IN ANAESTHESIOLOGY II. EVOLUTION OF HEAT AND MOISTURE IN THE LARGE CARBON DIOXIDE ABSORBERS
}

\author{
R. DÉRX, M.D., F.R.G.P.(c), J. PELLLETIER, M.D., \\ A. JACQUES, M.D., F.R.C.P.(C), F.F.A.R.C.S., \\ M. Clavet, M.D., and J. J. Houde, M.D."
}

THE ACCEPTANCE of the giant-size carbon dioxide absorbers has steadily increased since they first came to be used during anaesthesia. From many points of view they have contributed a major improvement to the technical aspect of carbon dioxide chemical treatment. The large canisters nowadays available can hold 3 $\mathrm{kg}$. or more of absorbent; some are divided into communicating chambers, others can accommodate pre-packed plastic containers. Being transparent, they offer to the busy anaesthetist an easier means of monitoring soda-lime exhaustion. The absorption efficiency is increased, regeneration and activity occur simultaneously, and moreover, longevity is greatly prolonged. The over-all performance of the large absorber, first expected to last 16 to 20 hours during anaesthesia with the semiclosed system, was re-evaluated in 1964 by Brown, Seniff, and Elam. ${ }^{1}$ Surprisingly, they found the life expectancy prolonged up to 90 hours with a particular arrangement of the elements of the semi-closed system.

Thus relieved of the burden of the close attention required by the absorption unit, anaesthesiologists have seemingly lost some interest in the peculiar problems focused on these tiny granules. Little has been added in this field to the exhaustive pioneer work of Waters, ${ }^{2}$ Adriani, ${ }^{3}$ and Rovenstine, ${ }^{4}$ who under the circumstances limited their studies to absorbers of a smaller type. Many questions, as those pertaining to the evolution of humidity and temperature in these new devices, have been left with incomplete and provisional answers.

It is conventional to refer to the humidity content found in the inspiratory limb of the circle as emanating from three main sources: (1) the humidity from the expired air bypassing the soda lime absorber, (2) the water evolved from the neutralization of carbon dioxide, and (3) the moisture extracted from the structural hydration of the granules. Various authors disagree widely as to the part played by each of these sources. In the absence of experimental data, this matter has remained in the realm of speculation. Clark ${ }^{4}$ reported in 1954 that the inhaled gases return to the patient saturated because of the water produced by the neutralization reaction between carbon dioxide and soda lime. Adriani ${ }^{5}$ agrees that the greater portion of the humidity is derived from this reaction, but adds that some is obtained from the patient's lung. The moisture content of the granule, in the opinion of most authors, facilitates carbon dioxide absorption. Little concern has been given to the hypothesis that it could contribute huge

-From the Department of Anaesthesia and Resuscitation, Hôtel-Dieu of Québec, Québec, P.Q.

Can. Anaes. Soc. J., vol. 14, no. 3, May, 1967 
amounts of moisture to inhaled gas mixtures. While working on the subject of "air conditioning in anaesthesia systems, we investigated this possibility.

\section{METHODS}

The absorbers used during this investigation were Ohio Heidbrink no. 20 absorption heads, which can accommodate an average of $3 \mathrm{~kg}$. of fresh material. Before each experiment, the canister was filled up either with Sodasorb (sodalime U.S.P.) or Calona (sodalime B.P.), both brands conforming to the same standards of moisture content. The percentage hydration of aliquots of $100 \mathrm{gm}$. of each product was determined by evaporation in a dry oven and found to range between 13 and 19 per cent. The duration of each experiment was limited to one hour. After this period, the soda lime was discarded.

In the operating room, during clinical anaesthesia, the absorbent was ventilated at a standard volume of $10 \mathrm{~L} . / \mathrm{min}$, as delivered by an Ohio ventilator intermittently cycling 15 times per minute. A constant volume of $4 \mathrm{~L}$. of fresh gas inflow, consisting of $2 \mathrm{~L}$. of oxygen and $2 \mathrm{~L}$. of nitrous oxide, was added to the expired air at the gas inlet to the absorber. The direction of flow was downward through the canister. Anaesthesia was administered with a semiclosed circle with the directional $Y$ swivel valve located near the endotracheal tube.

In the laboratory, the experiments were conducted in a similar way, expired air being simulated by mixtures of oxygen and carbon dioxide saturated with water vapor at $24^{\circ} \mathrm{C}$. A non-adiabatic saturator of the bubbling type, as described by Bartlett, ${ }^{6}$ was used to deliver controlled moisture concentrations to the gas mixture intermittently perfusing the soda lime absorber.

Throughout these experiments, three parameters were analysed: temperature and relative and absolute humidities. Determinations were obtained at three standard levels in the absorber: in the centre of the higher chamber, where the chemical reaction occurred; in the upper part of the lower canister; then at its bottom, close to the outflow tract to the inspiratory limb of the circle. Convenient holes were drilled in the walls of the canister to accommodate thermometers or sampling tubes. Temperature was monitored either with laboratory mercury thermometers of high accuracy or with calibrated electrodes from a Yellow Springs multichannel Telethermometer. Relative humidity was measured with a modified dew-point hygrometer built and calibrated in our laboratory. The performance and the principles of operation of this instrument have been described in some detail in a previous report. ${ }^{7}$ Sampling was achieved at peak-flow during the inspiratory phase of respiration, by drawing aliquots of 30 c.c. of the gas under test through the sampling tube and chamber of the hygrometer for ten consecutive respiratory cycles. Absolute humidity was determined with a two-stage gravimetric method. In the first stage, the humidity content of the test gas was condensed in a refrigerated glass coil. In the second stage, the gases issuing from the coil were passed through a series of three canisters filled with anhydrous calcium chloride. Completion of moisture absorption, using this method, was insured by the absence of any weight gain in the last calcium chloride canister. 


\section{Observations and Results}

The following experiments were designed to collect data that would enable us to discriminate the contribution of each of the three aforementioned sources of moisture, and to infer the probable behaviour of the whole absorption system.

\section{Measurement of Perigranular Temperature in a Condition of No Flow}

Temperature readings were obtained from the centre of a fresh soda lime canister after 24 hours of exposure to ambient temperature $\left(24^{\circ} \mathrm{C}\right.$.) and humidity (53\% relative). The value obtained was $1^{\circ} \mathrm{C}$. lower than room temperature. Since this was related to the latent heat of vaporization, we deduced the hypothesis that a gradient of water vapour pressure should exist between perigranular space and ambient air. Air motion, temperature, and $\mathrm{P}_{\mathrm{H}_{2} \mathrm{O}}$ difference were the parameters kept in mind as possible influences in this evaporative process.

\section{Measurement of the Relative Humidity in the Perigranular Space}

Samples of perigranular space were obtained from the centre of a fresh absorber under static conditions, viz. without gas flow through the canister. Both ends of the canister were open to ambient atmosphere. Hygrometric determinations on five samples at $24^{\circ} \mathrm{C}$. indicated a mean relative humidity of 80.1 per cent (S.D. 2.2), corresponding to a partial tension of water vapour of $17.8 \mathrm{~mm}$. $\mathrm{Hg}$. Thus, stagnant air in contact with the moist surface of the granules eventually assumes a $\mathrm{P}_{\mathrm{H}_{2} \mathrm{O}}$ which is not very far from saturation at room temperature.

The influences of both temperature and flow on perigranular humidity were then evaluated. Figure 1 shows that variations in flow between 0 and $20 \mathrm{~L} . / \mathrm{min}$., using dry oxygen to perfuse the absorbent, induced no significant change in peri-

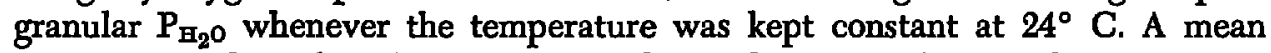
relative humidity of 82.5 per cent was observed (S.D. 2.3). Two determinations were obtained from fresh canisters of Sodasorb pre-paks. At a room temperature of $23.3^{\circ} \mathrm{C}$., relative humidity readings of 78 and 81 per cent were found. Determinations of perigranular relative humidity were repeated on 24 different occasions with the intermittent flow of $10 \mathrm{~L}$. $/ \mathrm{min}$. of dry oxygen through the absorbent. The relative humidity exhibited almost no variation, averaging 78.5 per cent (S.D. 9) at $24^{\circ} \mathrm{C}$.

These results suggest that within certain limits the total flow of gases used to ventilate the absorbent exerted no direct influence on the relative humidity of the perigranular space. In other words, flow rates from 0 to $20 \mathrm{~L} . / \mathrm{min}$. of dehydrated gas were well below the maximal humidifying capacity of the granules. This thesis is easily acceptable, knowing the tremendous surface area offered to vaporization by the mass of granules and the close contact between the phases.

Temperature variations in the absorbent, on the contrary, induced significant changes in the relative humidity both in the perigranular space and in the inspiratory limb of the circle, the first being ultimately reflected in the latter. To study the relationship between perigranular $P_{\mathrm{H}_{2} \mathrm{O}}$ and temperature in the absence of gas flow through the absorber, a heating pad was wrapped around the canister. A rheostatic control permitted readings to be obtained in a steady state at every 


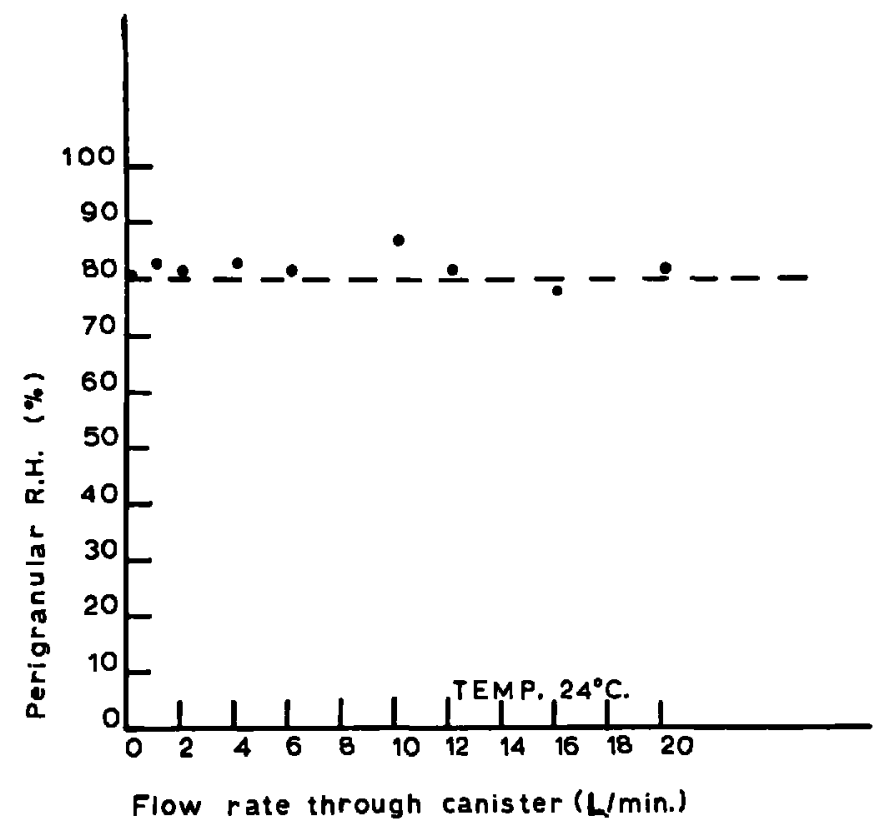

Figure 1. Relationship between perigranular relative humidity and gas flow rates throughout the absorbent. Samples were obtained from the lower part of the canister, at a constant temperature of $24^{\circ} \mathrm{C}$.

two or three degrees of temperature. The results are illustrated in Figure 2. Heating increased perigranular humidity progressively and linearly up to $37^{\circ} \mathrm{C}$,

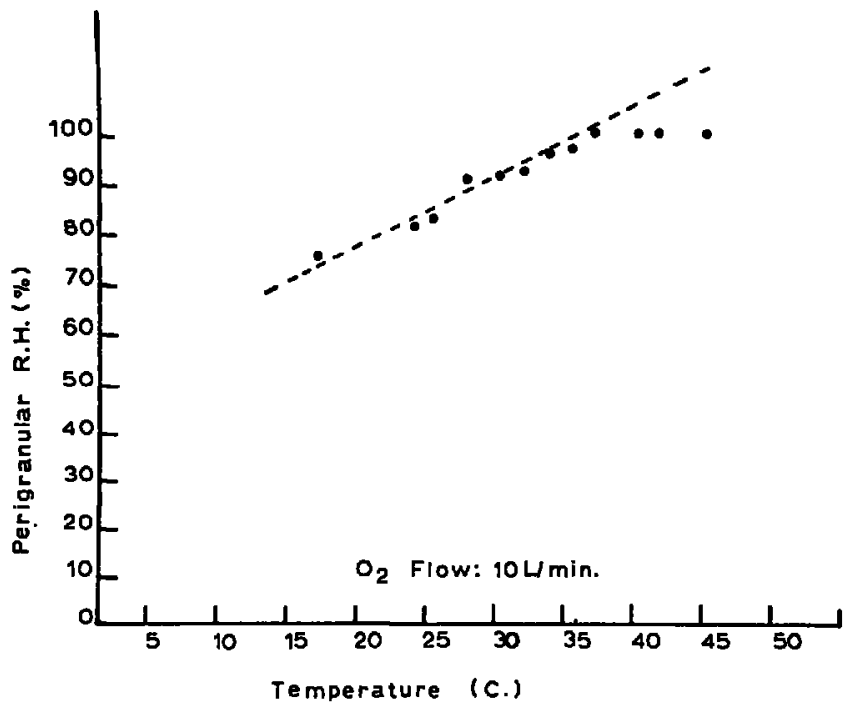

Frgure 2. Effect of temperature variations upon the relative humidity of the perigranular space. Samples were obtained from the lower chamber of the absorbent during intermittent perfusion with oxygen at the rate of $10 \mathrm{~L} . / \mathrm{min}$. 
when saturation occurred. Further heating promoted condensation of the saturated moisture on the granules and on the walls of the canister. Cooling of the canister decreased evaporation from the granules and lowered the relative humidity in the perigranular space.

This relationship between perigranular $\mathrm{P}_{\mathrm{H}_{2} \mathrm{O}}$ and temperature was also evaluated during perfusional experiments using an I.P.P.B. flow of $10 \mathrm{~L} . / \mathrm{min}$. of dry gas and a heating coil inside the canister. The results obtained will be given later in this report; they agree with those just mentioned under static conditions. In the whole, these results do not follow the well-known principle that relative humidity is an inverse function of temperature. They do agree with the fact that vaporization is directly proportional to temperature.

\section{Perfusion of the Absorbent with a Dry Gas}

Dehydrated oxygen was intermittently added to the semi-closed system by means of an automatic respirator at the rate of $10 \mathrm{~L} . / \mathrm{min}$. At the end of one hour, $12 \mathrm{gm}$. of water were extracted from the absorber, as measured in absolute humidity. Meanwhile, the relative humidity at the outflow of the canister yielded a constant reading at 80 per cent $( \pm 2.4 \%)$. The evolution of temperature in the absorber followed the pattern of a linear decrease in the upper chamber of the canister, from $24^{\circ} \mathrm{C}$. at the beginning of the perfusion to $12^{\circ} \mathrm{C}$. at the end of one hour. In the centre of the canister, temperature fell slightly from $24^{\circ}$ to $22^{\circ}$ by the termination of the experiment. In the lower part of the absorbent, no significant variation in temperature could be registered in one hour. This experiment was repeated four times, with identical results. The same amount of water was vaporized by soda lime and released in the inspiratory limb of the circle each time, albeit the absorbent was ventilated with a gas inflow completely dry and devoid of carbon dioxide.

\section{Perfusion of the Absorbent with Dry Oxygen and Carbon Dioxide}

On a theoretical basis, if some water is liberated by the neutralization of carbon dioxide by alkali and becomes available to humidify the inspired air, there should exist a linear relationship between the chemical reaction and the water output from the absorbent. This hypothesis was submitted to the following tests. First, soda lime was perfused at a standard flow rate of $10 \mathrm{~L} . / \mathrm{min}$., using a mixture of dry oxygen along with 1 per cent carbon dioxide. After one hour, the yield of water was $11.31 \mathrm{gm}$., with a relative humidity of 84 per cent in the inspiratory limb of the circle at a temperature of $24^{\circ} \mathrm{C}$. Temperature evolution in the canister is quite remarkable. There occurred a very slight increase in temperature, from $24^{\circ}$ to $26.6^{\circ} \mathrm{C}$. in the upper chamber, while the temperature remained constant at $24^{\circ} \mathrm{C}$. in the lower part of the canister. When the canister was perfused with 0.8 per cent carbon dioxide in oxygen, no variation in temperature occured in the whole canister, the heat of neutralization being exactly balanced by the latent heat of evaporation of the $12 \mathrm{gm}$. of water released.

When 2 per cent carbon dioxide in oxygen was perfused through the absorber in a similar way, the following results were obtained after one hour. An absolute humidity of $11.13 \mathrm{gm}$. of water (mean of two experiments), and a relative 
humidity of $\mathbf{7 8 . 2}$ per cent were liberated from the lower part of the absorbent to the inspiratory limb of the circle, where similar temperatures of $24^{\circ} \mathrm{C}$. could be read. Similarly, the perfusion of 3 per cent $\mathrm{CO}_{2}$ in dry oxygen extracted 10.28 gm. of water, as measured by the gravimetric method, while the hygrometer registered a relative humidity of 80.7 per cent at the outflow side of the canister. At 4 per cent $\mathrm{CO}_{2}$, the total yield of water began to rise. Two experiments of one hour each disclosed very similar results; 14 and $13.83 \mathrm{gm}$. of water were extracted from soda lime by $600 \mathrm{~L}$. of inflowing gases. A relative humidity of 100 per cent was soon noticed in the lower chamber of the absorbent, and condensation appeared in the inspiratory limb of the circle. The study of temperature and hygrometry in the absorber was revealing: the yield of water increased from the very moment the temperature began to rise in the lower chamber of the canister.

Perfusion of the system with 5 per cent carbon dioxide in dry oxygen yielded 24 c.c. of water in one hour, and again, the relative humidity soon reached a saturution level in the outflow tract of the canister, where a temperature of $45.5^{\circ}$ C. was recorded. The temperature curves illustrated in Figure 3, when compared with absolute and relative humidity data, give the key to the evolution of heat and moisture in the large soda lime absorbers.

For a given concentration of carbon dioxide, the temperature rises in the upper part of the absorbent until it reaches a plateau. A few moments before the plateau is attained, heat is evolved in the centre of the absorber until the same plateau is established in this area. Then the same phenomenon occurs in the lower part of the canister. In practice, with carbon dioxide concentrations below 3 per cent, temperature changes take place mostly in the upper chamber, without significant variations in the lower part of the canister. With $\mathrm{CO}_{2}$ concentrations higher than 3 per cent, heat is eventually evolved in the lower chamber.

Our results indicate that the relative humidity in the perigranular space followed the same pattern. For concentrations of $\mathrm{CO}_{2}$ below 3 per cent, perigranular $\mathrm{P}_{\mathrm{H}_{2} \mathrm{O}}$ and its counterpart, inspired air, $\mathrm{P}_{\mathrm{H}_{2} \mathrm{O}}$, both remained quite constant near 80 per cent at $24^{\circ} \mathrm{C}$. Whenever higher carbon dioxide concentrations were circulated in the canister, both water vapour tension and temperature eventually increased in the lower part of the absorbent, and saturated heated gases reached the inspiratory limb of the circle.

The relationship between carbon dioxide concentrations and water output from the canister is far from linear, as illustrated by our data. This should indicate that carbon dioxide absorption plays only an indirect role in the liberation of water to ambient gases. Our results suggest that the exothermic reaction was responsible for the greater moisture production. This was further demonstrated in experiments where, instead of perfusing the large soda-lime canister with mixtures containing carbon dioxide, we used an acapnic gas with a heating coil wound in the mass of the granules to imitate the exothermic process of carbon dioxide absorption.

\section{Perfusion of a Heated Absorbent with an Acapnic Dry Gas}

Hot water was circulated in a rubber coil situated in the absorbent, until a steady temperature of $30^{\circ} \mathrm{C}$. was obtained in the perigranular space. This tem- 

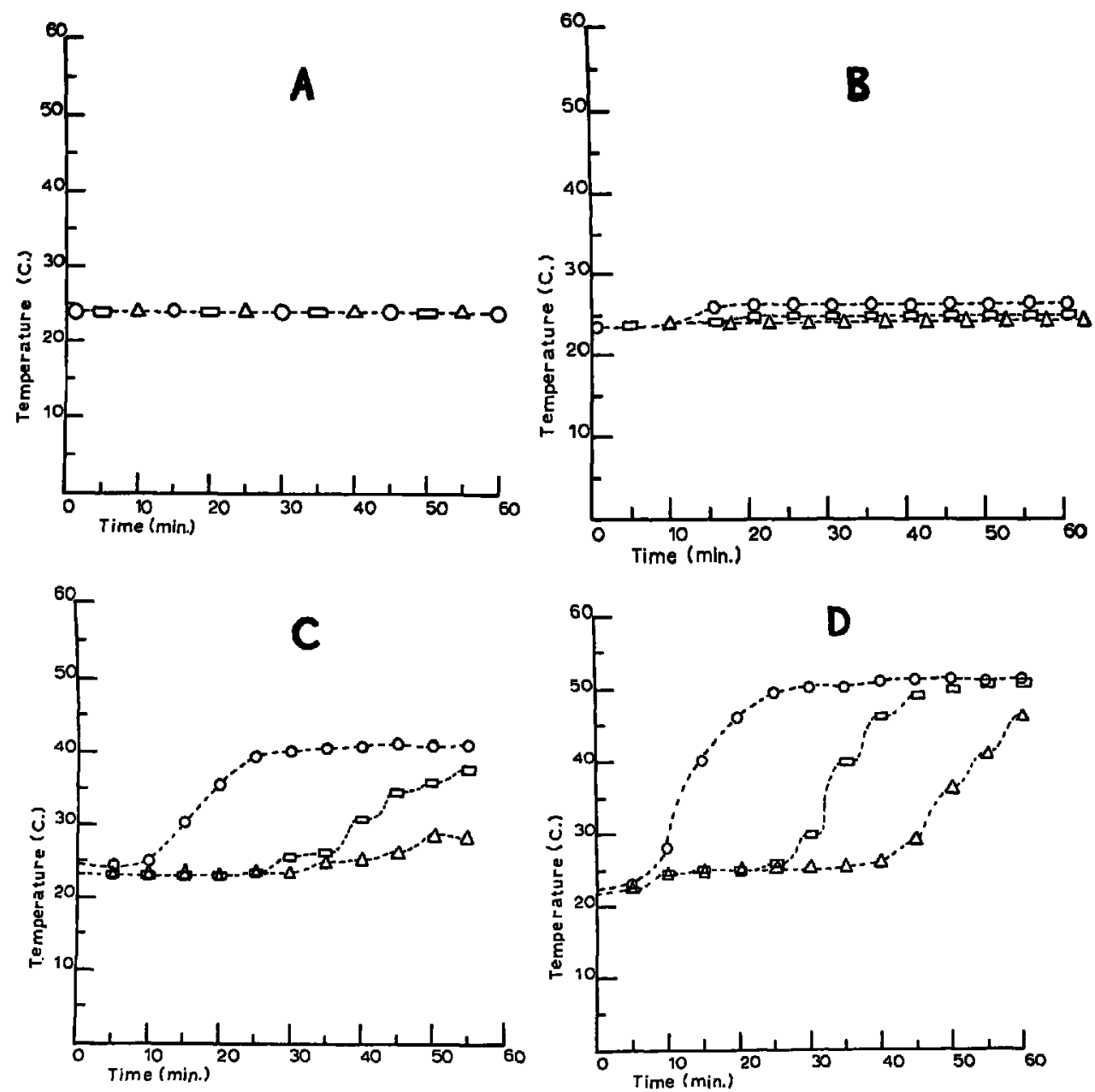

Figure 3. Evolution of temperature at three conventional sites in the large soda-lime absorber during intermittent perfusion with dry oxygen and various concentrations of carbon dioxide. The circles represent temperature in the upper part of the canister; the rectangles, temperature in the centre; and the triangles, temperature in the lower part. Concentrations of carbon dioxide for graph A are 0.8 per cent; for graph B, 1.0 per cent; for graph C, 3.0 per cent; and for graph $\mathrm{D}, 5.0$ per cent.

perature corresponds to the plateau attained by the passage 2 per cent carbon dioxide. A flow of $10 \mathrm{~L} . / \mathrm{min}$. of dry oxygen was then ventilated through the system for one hour. At the end of the experiment, a total amount of $12.4 \mathrm{gm}$. of water was collected. Similarly, dry oxygen was perfused through the absorbent heated at $42^{\circ} \mathrm{C}$; this approximately represents the plateau occuring with 4 per cent carbon dioxide. An amount of $14.4 \mathrm{gm}$. of water was extracted in one hour. The same experiment was repeated with a constant perigranular temperature of $50^{\circ} \mathrm{C}$. in order to reproduce the conditions offered with 5 per cent carbon dioxide. Under these conditions, after one hour of perfusion with a dry gas, $24.4 \mathrm{gm}$. of water were released from the absorbent. These results approximate those obtained while perfusing soda-lime with corresponding concentrations of carbon dioxide. 
They demonstrate that the exothermic process alone activates and liberates the water molecules already in a free state on the surface of the granules and not chemically involved in the neutralization reaction.

\section{Perfusion of the Absorbent with Acapnic Moist Air}

The humidity of exhaled air was evaluated as a source of water to humidify the inspired gas mixture during anaesthesia with the semi-closed circle. The questions to be answered were the following. Can the water vapour of the exhaled air bypass soda-lime? What is the influence exerted by the addition of various amounts of dry gas from the debimeters to the saturated expired air before it reaches the absorber?

The large Ohio canister was first perfused with $10 \mathrm{~L} . / \mathrm{min}$. of oxygen saturated with water vapor at $24^{\circ} \mathrm{C}$. Six hundred litres of this perfusing mixture released $12.8 \mathrm{gm}$. of water after one hour. The relative humidity decreased from a control reading of 100 per cent at the top of the absorber to 82.8 per cent at the outlet, both sampling sites remaining at $24^{\circ} \mathrm{C}$. No change in temperature was noticed at the three standard levels in the canister. This fact is important and should be compared with the tremendous decrease in temperature which was demonstrated in the upper chamber of the canister whenever perfused with a dry acapnic gas. The temperature stability just mentioned suggested that no evaporation took place on the granular surface, otherwise their temperature should have fallen. On the contrary, the saturated gas inflow underwent condensation owing to the $\mathrm{P}_{\mathrm{H}_{2} \mathrm{O}}$ gradient, as indicated by the decrease in relative humidity. The inflowing gas, saturated at room temperature, exerted a water vapour tension of $22.5 \mathrm{~mm}$. $\mathrm{Hg}$, whereas the perigranular space, as mentioned earlier, offered a relatively constant water vapour tension of $18 \mathrm{~mm}$. $\mathrm{Hg}$ at $24^{\circ} \mathrm{C}$. This gradient was nullified throughout the absorbent by the condensation of about 20 per cent of the relative humidity of the inflowing saturated gas. Consequently, we concluded that 80 per cent of the relative humidity of exhaled air had bypassed the soda-lime filter.

This proposition holds true only when the saturated exhaled air has not been contaminated with an inflow of dry gases from the anaesthesia machine. Using the semi-closed system, $4 \mathrm{~L}$. of new gas are commonly added to the circuit at the top of the canister. This lowers the relative humidity of exhaled air to approximately 66 per cent, corresponding to a $\mathrm{P}_{\mathrm{H}_{2} \mathrm{O}}$ of $15 \mathrm{~mm} . \mathrm{Hg}$. Accordingly, the mixture now enters the canister with a deficit of $3 \mathrm{~mm}$. $\mathrm{Hg}$ of $\mathbf{P}_{\mathrm{H}_{2} \mathrm{O}}$, and extracts additional water from the granules until it reaches a relative humidity of 80 per cent at the outflow tract of the circle. This phenomenon was duplicated in the laboratory by perfusing the canister with $10 \mathrm{~L}$. $/ \mathrm{min}$. of oxygen at a relative humidity of 50 per cent, corresponding to a $\mathrm{P}_{\mathrm{B}_{2} \mathrm{O}}$ of $11.2 \mathrm{~mm}$. $\mathrm{Hg}$ at $24^{\circ} \mathrm{C}$. The total amount of water collected at the end of one hour was 11.6 gm., while the relative humidity remained at 80 per cent at the lower part of the canister. Temperature of the absorbent in the upper chamber decreased $5^{\circ} \mathrm{C}$. during the experiment, indicating water evaporation from the granules to the inflowing gas.

In clinical practice, the following proposition should be accepted from our data. With a low flow of diluent gases from the debimeters, the relative humidity of exhaled air suffers little dilution and enters the absorbent with a $\mathbf{P}_{\mathrm{H}_{2} \mathrm{O}}$ approxi- 
mating that of perigranular air. Little or no water is evolved from the granules; that is to say, exhaled air humidity effectively bypasses the absorbent. With use of moderate to high flow rates of diluents, there is greater evaporation from the granules to humidify the outflowing gas mixture to 80 per cent at $24^{\circ} \mathrm{C}$.

\section{Perfusion of the Absorbent with Exhaled Air during Clinical Anaesthesia}

One patient was anaesthetized for three hours with the semi-closed circle absorption with a gas flow of $2 \mathrm{~L} . / \mathrm{min}$. of oxygen and $2 \mathrm{~L} . / \mathrm{min}$. of nitrous oxide. Ventilation was kept constant at $10 \mathrm{~L} . / \mathrm{min}$. Temperature, relative humidity and carbon dioxide concentrations in the canister were monitored throughout. With this flow, large amounts of carbon dioxide were lost through the expiratory valve. The fresh gas entered the system between the expiratory valve and the absorber. Gas entering the canister had a mean concentration of 2 per cent carbon dioxide, as indicated with an infrared monitor. The temperature in this area reached a plateau of $32^{\circ} \mathrm{C}$. after two hours and remained constant thereafter. Incidentally, this increase in temperature closely duplicates the results obtained in the laboratory, using 2 per cent carbon dioxide to perfuse the absorbent. During the third hour of anaesthesia, temperature rose from $24^{\circ}$ to $29^{\circ} \mathrm{C}$. in the centre of the absorber. Sampling here indicated 0 per cent of carbon dioxide. No change in temperature occured in the lower part of the absorbent, which remained essentially at room temperature. This fact is of utmost importance since it means that during three hours of conventional anaesthesia, the perigranular $\mathrm{P}_{\mathrm{H}_{2} \mathrm{O}}$ remained constant at $18 \mathrm{~mm}$. $\mathrm{Hg}$ ( 80 per cent R.H. at $24^{\circ}$ C.) at the outflow tract of the absorber. Accordingly, the inspired gas mixture leaving the absorption unit maintained the same temperature and humidity. These figures were in fact repeatedly confirmed by hygrometry in this particular case.

\section{Discussion}

The availability of the moisture content of the soda-lime canister in providing humidity to inspired gases is well demonstrated in our experiments. This characteristic of soda-lime may be expressed in figures. A well-packed canister, of the large size, containing $3000 \mathrm{gm}$. of granules, should theoretically yield approximately $570 \mathrm{ml}$. of water before total dehydration. This amount of water represents a capacity to yield $12 \mathrm{ml}$. of water per hour for a predicted duration of 48 hours, with a ventilation of $10 \mathrm{~L} . / \mathrm{min}$. at a relative humidity of 80 per cent at $24^{\circ} \mathrm{C}$. In practice, this duration is prolonged by the rebreathing of exhaled air saturated with moisture.

Our results suggest that no water is directly contributed by the chemical combination of carbon dioxide with alkali. Only two sources remain as components of the water pool from which humidity of inspired air can be evolved: exhaled air moisture and water content of the granules. The latter is located both in the granular and in the perigranular space, presumedly in the liquid phase in the first and in the gaseous phase in the latter. Our results suggest an important relationship between these two phases. Within certain limits of ventilation and as long as temperature is kept constant, the partial tension of water vapour 
surrounding the granule is invariable. As illustrated by our data, at a room temperature of $24^{\circ} \mathrm{C}$, perigranular $\mathrm{P}_{\mathrm{H}_{2} \mathrm{O}}$ is constant at $18 \mathrm{~mm}$. $\mathrm{Hg}$, a tension corresponding to a relative humidity of 80 per cent. By comparison, one could assimilate the granular and the perigranular spaces to some kind of humidifying buffer pair, with a pK of $18 \mathrm{~mm}$. $\mathrm{Hg}$ or 80 per cent relative humidity at $24^{\circ} \mathrm{C}$. The flow of anaesthetic gases delivered through the absorbent by ventilation comes into close contact with this granular-perigranular pair, equilibrates its $\mathrm{P}_{\mathrm{H}_{2} \mathrm{O}}$ with that of the water buffer, and finally leaves the soda-lime canister ideally buffered or conditioned at a $\mathrm{P}_{\mathrm{H}_{2} \mathrm{O}}$ of $18 \mathrm{~mm}$. $\mathrm{Hg}$ for a soda-lime temperature of $24^{\circ} \mathrm{C}$. This equilibrium between partial tensions of water vapour follows Fick's law. Whenever perfusing gas exerts a $\mathrm{P}_{\mathrm{H}_{2} \mathrm{O}}$ higher than that of the perigranular space for a given temperature, a gradient of $\mathrm{P}_{\mathrm{H}_{2} \mathrm{O}}$ is created which favours water gain by the granule until a hygroscopic equilibrium is reached at this particular temperature. As demonstrated by our results, perfusion of the soda-lime with a dehydrated gas means water loss from the granules. The total amount of water in the liquid phase in the granular space is now reduced. However, the $\mathrm{P}_{\mathrm{H}_{2} \mathrm{O}}$ in the surrounding perigranular. space is unchanged, since the partial tension above a liquid phase is independent of the absolute amount of the liquid.

We have shown that during clinical anaesthesia with the semi-closed system, using a $4 \mathrm{~L} . / \mathrm{min}$. gas flow from the debimeters and a total ventilation of 10 L./min., water was given up by the granules and consequently a decrease in temperature should occur in the upper part of the canister owing to the latent heat of vaporization. In practice, why is no temperature decrease noticed in this area? The potential fall in temperature is countered by the exothermic reaction of carbon dioxide and alkali. In fact, the temperature reading at this site is the result of many factors which are illustrated in Table I. A steady-state equilibrium

TABLE I

Heat Balance in the Soda-lime Absorber

\begin{tabular}{ll}
\hline \multicolumn{1}{c}{ Heat gain } & \multicolumn{1}{c}{ Heat loss } \\
\hline 1. Heat of neutralization & 1. Latent hent of vaporization \\
2. Heat of solution & 2. Radiative and convective heat losses: \\
3. Latent heat of condensation & $\begin{array}{l}\text { a. cooling by new gas infow at room temperature } \\
\text { b. heat irradiation to the walls of the canister; }\end{array}$ \\
& $\begin{array}{l}\text { c. heat convection to the granules underlying } \\
\text { the absorption process. }\end{array}$ \\
\hline
\end{tabular}

between factors of heat gain and of heat loss explains the occurrence of a temperature plateau in soda-lime for a given amount of carbon dioxide.

Table $\mathbf{I}$ tabulates thermodynamic factors such as heat radiation and convection to the underlying layers of inactive granules which are operative in achieving heat balance in the soda-lime absorber. The use of carbon dioxide detection apparatus (the Godart Capnograph) throughout the experiments permitted us.to gain more insight into these phenomena. The chemical absorption of carbon dioxide was completed at a surprisingly high level in the large canister. Believing that heat production was due to a chemical reaction at that site, we were surprised, when perfusing soda-lime with 5 per cent carbon dioxide, to read a 
temperature of $50^{\circ} \mathrm{C}$. in the whole absorber, although the existence of a chemical reaction could be demonstrated only at the top of the absorbent.

We have concluded from our data that the humidity of gases emerging from a large soda-lime canister is relatively constant under varying experimental and clinical conditions. These conditions include perfusion with a dry gas, with a dry acapnic gas, with a saturated acapnic gas, with a dry gas containing up to 3 per cent carbon dioxide, and with moist gas containing carbon dioxide in "clinical" concentrations. Common to all these variables is an outflow temperature of $24^{\circ}$ C., i.e. room temperature. The humidity of emerging gases is a function of the $\mathbf{P}_{\mathrm{B}_{2} \mathrm{O}}$ in the perigranular space at the outflow side of the canister. At any given temperature, the $\mathrm{P}_{\mathrm{H}_{2} \mathrm{O}}$ is constant and represents 80 per cent of the saturation vapour pressure. The perigranular $\mathrm{P}_{\mathrm{H}_{2} \mathrm{O}}$ constant for a given temperature can be expressed by the following formula:

$$
\text { Perigranular } \mathrm{P}_{\mathrm{B}_{2} \mathrm{O}}=80 \mathrm{e}_{\mathrm{w}} \text { (Ts)/100 }
$$

where $e_{w}$ is saturated water vapour pressure and Ts is the sampling temperature.

This figure, in millimetres of mercury, can be translated into terms of relative humidity by the equation:

$$
\text { R.H. }=\left(\text { Perigranular } \mathrm{P}_{\mathrm{H}_{2} \mathrm{O}}\right) /\left[\mathrm{e}_{\mathrm{w}}(\mathrm{Ts})\right]
$$

Data pertaining to water vapour pressure are obtainable by reference to standard tables. Using this formula, relative humidity of the inspired gas mixture may be predicted simply by monitoring the temperature in the proximal end of the soda-lime canister.

We may wonder why the perigranular relative humidity is at or near 80 per cent at a room temperature of $24^{\circ} \mathrm{C}$. Why not 100 per cent or 50 per cent? The answer to this question may be found experimentally, but its explanation remains obscure. It involves complex facts of physical chemistry that we shall now try to summarize. According to the kinetic theory, there is a continuous flight of molecules from the surface of a liquid into the free space around it. At the same time, molecules of vapour return to the surface of the liquid at a rate depending on the concentration of the vapour. Eventually, a condition of equilibrium is established between the liquid and its vapour, when the rate of escape is exactly equal to the rate of condensation of vapour. The vapour is then said to be saturated for a given temperature. This is the case with pure water. Figure 4 tentatively illustrates this phenomenon.

The water content of the granules is assumed to be in a liquid form in which non-volatile solutes, $\mathrm{NaOH}, \mathrm{Ca}(\mathrm{OH})_{2}$ and $\mathrm{KOH}$ are dissolved. The molecules of water escaping from a solution, at a given temperature, never reach the saturation vapour pressure of the pure solvent, viz. water. The molecules of sodium, calcium, and potassium hydroxides lower the escape tendency, i.e., the vapour pressure, of water by kinetic interference at the interphase. This is depicted in Figure 4, where the molecules of solute are shown to cause physical hindrance to the free escape of water molecules. Moreover, the same figure demonstrates that, on the surface of the soda-lime granule, the effective concentration of water is reduced by other molecules. In other words, the total number of water molecules trying to escape at the surface is somewhat diluted by a number of non-volatile solute 

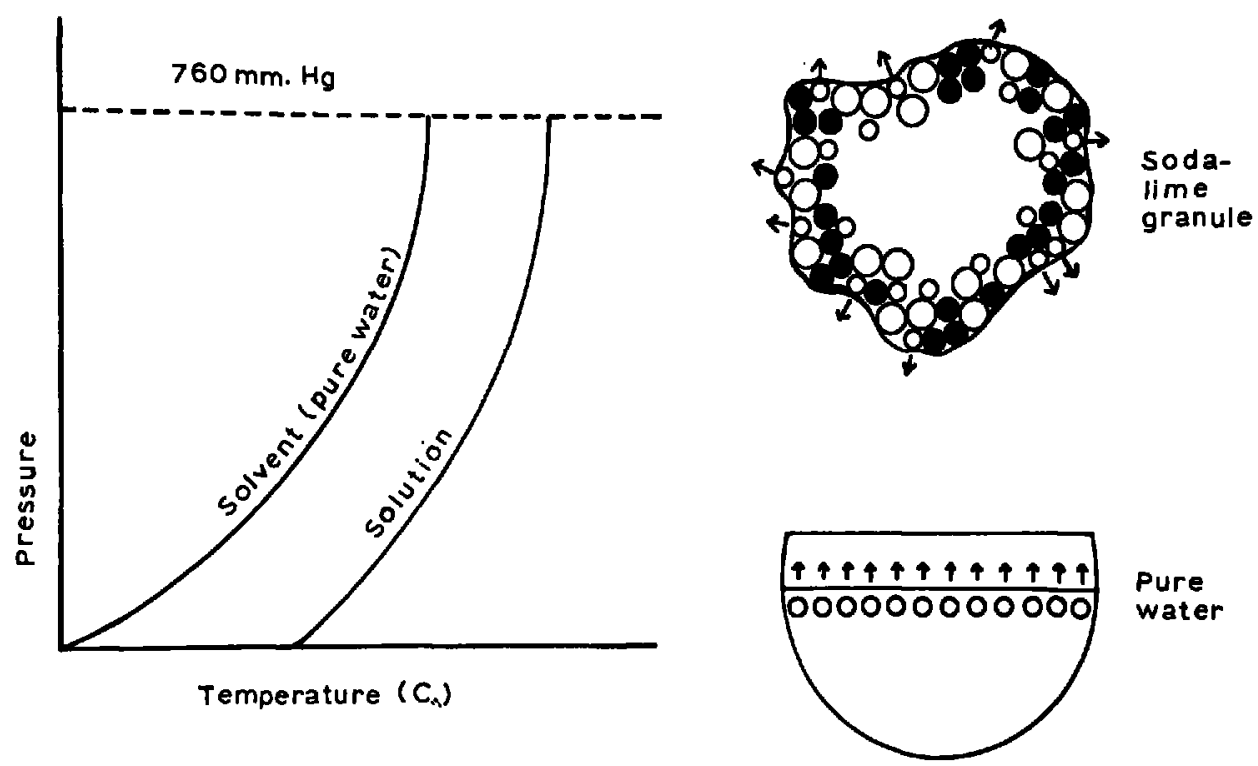

Ficure 4. Illustration of Raoult's law. In the diagram on the left, the curve representing the vapour pressure of pure water is lowered (displaced to the right) by the addition of nonvolatile solutes. The diagrams on the right depict the same phenomenon in another way. Note the electrokinetic hindrance exerted on water molecules at the interphase of the granules by other molecules.

molecules. This therefore lowers the vapour pressure of the solvent, as Raoult's law states: the lowering of the vapour pressure of a solution divided by the vapour pressure of the pure solvent is equal to the mole fraction of the solute. ${ }^{8}$ In his princeps experiments in 1888, Raoult found that when $2.47 \mathrm{gm}$. of ethyl benzoate were dissolved in $100 \mathrm{gm}$. of benzene at $80^{\circ} \mathrm{F}$. the vapour pressure was lowered from 751.9 to $742.6 \mathrm{~mm}$. $\mathrm{Hg}$. We can therefore understand how, by dissolving soda-lime in 14 to 19 per cent of water at $24^{\circ} \mathrm{C}$., the vapour pressure of water is lowered from 22.5 to $17.8 \mathrm{~mm}$. $\mathrm{Hg}$, and accordingly how its relative humidity falls from saturation level to 80 per cent.

It is more difficult to explain why perigranular $\mathrm{P}_{\mathrm{H}_{2} \mathrm{O}}$ was found constant for a given temperature and, as suggested by our results, remained relatively independent of flow rates through the absorbent. Whenever water is added to dehydrated soda-lime, it is incorporated into the alkali crystals to form hydrates: $\mathrm{NaOH} \cdot n \mathrm{H}_{2} \mathrm{O}$, $\mathrm{Ca}(\mathrm{OH})_{2} \cdot n \mathrm{H}_{2} \mathrm{O}$, and $\mathrm{KOH} \cdot n \mathrm{H}_{2} \mathrm{O}$. The exact nature of these hydrates is not precisely known. However, the same general principles which apply to dehydration of hydrates should apply to the hydrates found in soda-lime, whatever their complex heterogenicity. Dehydration of hydrates, at a constant temperature, yields a constant vapour pressure of water as long as the hydrate remains present in the solution. This is illustrated by the following classical example: whenever pentahydrate of $\mathrm{CuSO}_{4}$ undergoes dehydration at $50^{\circ} \mathrm{C}$., a water vapour pressure of $47 \mathrm{~mm}$. $\mathrm{Hg}$ is maintained around the crystal as long as any of the pentahydrate is present. From this fact, it is conceivable that the perigranular $\mathbf{P}_{\mathbf{H}_{2} \mathrm{O}}$ in soda-lime might remain constant for a given temperature as long as any 
hydrate exists in the granule. Let us repeat, however, that the structure of a soda-lime granule may include a very complex heterogeneous system of hydrates. Heterogenicity may involve a number of variables in the system: temperature, pressure, concentration of water and other molecules in the different phases. The influence of all these variables would need to be specified in order to define the system completely. This task is quite formidable and, admittedly, far outside our reach.

\section{SUMmary AND CONCLUSION}

The evolution of heat and moisture in the large modern absorbers have been investigated both in the laboratory and in the operating room, using the semiclosed circle. Our results suggest the following conclusions:

1. Little heat is evolved at the inflow site of the canister during clinical anaesthesia, with a $4 \mathrm{~L}$./min. fresh gas inflow from the debimeters. In our experiments with a standard ventilation of $10 \mathrm{~L} . / \mathrm{min}$., carbon dioxide averaged 2 per cent at the gas inlet to the canister. Heat produced by the exothermic reaction in this area is in part cancelled by the latent heat of vaporization.

2. Accordingly, the temperature at the lower end of the canister is little influenced by $\mathrm{CO}_{2}$ absorption and remains near room temperature.

3. Within certain limits, perigranular $\mathrm{P}_{\mathrm{H}_{2} \mathrm{O}}$ is unaffected by flow. However, it is highly dependent upon temperature changes. At a room temperature of $24^{\circ} \mathrm{C}$., perigranular water vapour tension is constant at $17.8 \mathrm{~mm}$. $\mathrm{Hg}$. This corresponds to a relative humidity of 80 per cent in the perigranular space.

4. Gas mixtures reach the outflow tract of the absorbent in a hygroscopic equilibrium with the perigranular $\mathbf{P}_{\mathrm{H}_{2} \mathrm{O}}$ found in the lower chamber of the sodalime.

5. The humidity content of the inhaled gas mixture is supplied by two main sources: the moisture content of the granules and the water vapour from exhaled air. The contribution of each source is determined by the volume of the dry diluent gases added to expired gases at the top of the absorber.

6. Carbon dioxide absorption probably does not directly contribute water to humidify the inspired gas. However, it may stimulate water evaporation from the granules warmed by this exothermic reaction.

7. The relative humidity of inspired air may be predicted by monitoring the temperature in the lower part of the absorbent.

The present investigation demonstrates that the inspired gas mixture carries a relatively constant water vapour averaging 80 per cent relative humidity at $24^{\circ} \mathrm{C}$. as it leaves the soda-lime canister. Studies currently in progress will evaluate the physiology of the respiratory mucous membranes when exposed to the gas issuing from the large carbon dioxide absorbers.

\section{Résumé}

Depuis l'avénement en anesthésie des canisters d'absorption à large contenu de chaux sodée, le maintien de la normocapnie s'est avéré une tâche facile pour 
l'anesthésiste. Moins préoccupé par l'évolution du $\mathrm{CO}_{2}$ dans les circuits d'anesthésie, l'investigateur se tourne vers d'autres aspects moins explorés inhérents a l'emploi de ces absorbeurs géants. Notre étude a tenté de préciser l'évolution de la température et de l'humidité au sein d'un circuit d'absorption placé dans des conditions fort variables quant au mélange gazeux perfusé, mais stables quant à la réalisation d'une ventilation intermittente de $10 \mathrm{~L} . / \mathrm{min}$. de volume pour une durée expérimentale d'une heure. Les paramètres mesurés ont été la température à certains niveaux du bocal de chaux, l'humidité relative périgranulaire et l'humidité absolue libérée par la perfusion. Nous avons mis en évidence que la perfusion cyclique décrite libère un chiffre à peu près standard de 12 c.c. d'eau sur une durée d'une heure, que le mélange perfusé soit du gaz sec ou du gaz saturé d'humidité à la température de la pièce, chargé ou non de $\mathrm{CO}_{2}$, en autant que la température demeure à $24^{\circ} \mathrm{C}$. à l'extrémité inférieure du canister. Nous avons également démontré que l'humidité relative, à cette température, conserve un niveau à peu près constant de 80 pour cent, chiffre qui correspond à une pression partielle de vapeur d'eau dans l'espace périgranulaire de $17.8 \mathrm{~mm}$. $\mathrm{Hg}$. L'addition de concentrations de $\mathrm{CO}_{2}$ supérieures à 3 pour cent dans le mélange perfuseur conduit à une libération plus grande d'eau par les granules; nos résultats indiquent que ce fait ne doit pas être rattaché directement d̀ l'occurrence de la réaction chimique, mais plutôt d̀ la production de chaleur qui augmente la vaporisation d'eau en surface du granule.

Le granule de chaux sodée devient en définitive une sorte de tampon hydrique qui, suivant la température de son ambiance et la tension de vapeur d'eau qui y règne, peut ou bien céder de son eau structurale ou encore s'hydrater davantage, jusqu’à ce qu'un équilibre soit établi, pour une températre donnée, entre la phase périgranulaire et la phase granulaire. Cet équilibre hygroscopique se situe, d'après nos résultats, à une humidité relative de 80 pour cent de la phase périgranulaire, chiffre qui équivaut, à $24^{\circ} \mathrm{C}$., à une $\mathrm{P}_{\mathrm{H}_{2} \mathrm{O}}$ de $17.8 \mathrm{~mm}$. $\mathrm{Hg}$.

Le canister géant de chaux sodée devient à son tour, grâce d̀ la surface immense offerte par les granules, un conditionneur très efficace de l'air inspiré qui le perfuse. Dans les conditions cliniques habituelles d'utilisation du circuit demi-fermé, l'air inspiré retrouvé dans le bras inspiratoire renferme une humidité relative de 80 pour cent tant et aussi langtemps que la partie inférieure de la masse granulaire demeure à la température de la pièce, soit $24^{\circ} \mathrm{C}$. Il devient ainsi facile de prédire l'humidité relative du mélange gazeux présenté au malade en inspiration à la simple condition de surveiller l'évolution de la température au sortir de la chaux. En principe, l'air inspiré au sortir de la chaux s'est équilibré parfaitement avec la $\mathbf{P}_{\mathrm{H}_{2} \mathrm{O}}$ périgranulaire pour une température donnée. Les corrections à faire en fonction de la température suivent la formule suivante:

$$
\mathrm{P}_{\mathrm{H}_{2}} \text { O périgranulaire }=80 \mathrm{e}_{\mathrm{w}} \text { (Ts) } / 100 \text {, }
$$

où l'expression $e_{w}$ correspond à la pression de saturation de la vapeur d'eau et Ts réfère la température d'echantillonnage. Au demeurant, ce résultat de $\mathbf{P}_{\mathrm{H}_{2} \mathrm{O}}$, en millimètres de mercure, peut être transformé en lecture d'humidité relative au moyen de l'équation suivante:

$$
\text { H.R. }=\left(\mathrm{P}_{\mathrm{H}_{2} \mathrm{O}} \text { périgranulaire }\right) /\left[\mathrm{e}_{\mathrm{w}}(\mathrm{Ts})\right]
$$


Cette prédiction s'est avérée reproductible à peu d'erreur près lors des déterminations d'humidité relative que nous avons effectuées dans la chaux sodée et dans le bras inspiratoire du circuit en utilisant un hygromètre "à point de rosée" de notre fabrication.

Le granule libère dans son ambiance un contingent de vapeur d'eau qui, sans causer la saturation de l'air périgranulaire d̀ la température de la pièce, entretient tout de même une humidité relative qui se situe au niveau élevé de 80 pour cent. Le fait que la saturation n'est pas obtenue tient à deux explications: les molécules de vapeur d'eau quittent avec une certaine difficulté la surface granulaire, déjà peuplée d'autres molécules différentes; de plus, il s'établit dans la chaux sodée des systèmes d'hydrates dont la distillation suit des lois rigides et bien définies. Les systèmes d'hydrates présents dans la chaux sont encore peu connus et mériteraient d'être approfondis.

En conclusion, nos résultats, encore au stage préliminaire et susceptibles d'être remodelés, laissent entrevoir un nouvel aspect de l'absorption du $\mathrm{CO}_{2}$ : le rôle de conditionnement thermique et hygroscopique joué par les granules à l'égard des gaz inspirés. La stabilité d'un tel système de conditionnement est assurée par la masse considérable de la charge sodée et par le peu de distorsions thermiques qui y surviennent dans des conditions usuelles d'emploi clinique.

\section{ACKNOWLEDGMENTS}

We are indebted to Mr. Pierre Saillant, medical student at Laval University, Québec, for his invaluable collaboration in this work during his summer vacation. Also we should like to thank Mr. André Dufresne and Miss Louise Bouchard, i.l., who prepared the figures.

\section{REFERENCES}

1. Brown, E. S.; SentrF, A. M.; \& ElaM, J. O. Carbon Dioxide Elimination in Semiclosed Systems. Anesthesiology. 25: 31 (1964).

2. Watens, R. M. Carbon Dioxide Absorption. Ann. Surg. 38: 105 (1936).

3. Adrini, J. \& Rovenstune, E. A. An Experimental Study of Carbon Dioxide Absorbers for Anesthesia. Anesthesiology. 2: 1 (1941).

4. Clank, R. E.; Orkin, L. R.; \& Rovenstine, E. A. Body Temperature Studies in Anesthetized Man. J.A.M.A. 154: 311 (1954).

5. Adriani, J. The Chemistry and Physics of Anesthesia. 2nd ed., Springfield: Thomas (1962).

6. Bartuetr, E. P. The Concentration of Water Vapor in Compressed Hydrogen, Nitrogen and a Mixture of These Gases in the Presence of Condensed Water. J.Am.Chem.Soc. 49: 65 (1927).

7. Déry, R.; Pelcetier, J.; Jacques, A.; Claver, M., \& Houde, J. J. Humidity in Anaesthesiology. I. A Modified Dew-point Hygrometer. Canad. Anaesth. Soc. J. 14: 104 (1967).

8. Getman, F. H. Outlines of Physical Chemistry. 7th ed. (F. Daniels), New York: Wiley (1943). 